\title{
The origin and formation of the Transbaikal health care system
}

\author{
Sergey D. Batoev ${ }^{1}$ \\ 1 FSAEI HE I.M. Sechenov First MSMU MOH Russia (Sechenov University) \\ 8 Trubetskaya St., building 2, Moscow 119991, Russia
}

Corresponding author: Sergey D. Batoev (sbatoev@list.ru)

Received: 06 August 2018 Accepted: 23 November 2018 Published online: 31 December 2018

Citation: Batoev SD (2018) The origin and formation of the Transbaikal health care system. History of Medicine 5(4): $248-255$. https://doi.org/10.3897/hmj.5.4.35650

\begin{abstract}
The current continuing outflow of valuable production forces and intellectual resources from Transbaikal has a negative impact on the socio-economic development of this border area. A retrospective analysis of the health care system provided to the Russian population living in remote areas demonstrates that not all formative stages of the health care system in Transbaikal were completed without problems. The Russian Empire implemented a state policy on the demographic and socio-cultural integration of Transbaikal for the purpose of rational economic development, effective consolidation of the territory and provision of border security. The pre-revolutionary government, facing significant financial shortages and an unfavorable socio-economic and political situation from the mid 18th century, carried out continuous work to create the foundations for the Transbaikal public health system. However, social issues were not a priority with regard to all population groups living on the outskirts of the Russian Empire, therefore many projects and decisions were implemented with significant delays or in a reduced format. In addition, it is necessary to take into account an objective point restraining the introduction of the central authorities' solution: a new type of medical care was being promoted, to which the indigenous and newly arrived people of Transbaikal had to grow accustomed. At the same time, by the beginning of the 20th century, the heterogeneous population of Transbaikal, which traditionally used folk methods as well as Tibetan medicine, gradually began to understand the advantages of official medicine and science-based hygiene for improving and preserving human potential, which is the basis of the physical and intellectual development of any nation, and to master their leading principles. From the beginning of November 1920, under the conditions found in the Far Eastern Republic, measures were taken for the first time to organize free and preventive medicine for all population groups on the territory of Transbaikal, which marked the beginning of positive changes in the sphere of health care in terms of ensuring the real availability of medical care.

Thus, the long process if creating a treatment and prevention system in pre-revolutionary Transbaikal took place within the framework of the all-Russian model of state medical care. It was continuous in nature and had a number of significant differences from the health care system established in European Russia.
\end{abstract}

\section{Keywords}

history of medicine, history of health care, Transbaikal region, military hospital, rural medicine, Far Eastern Republic

Transbaikal, along with other eastern areas of the Russian Federation, maintains its important role in the economic development of the country as a whole. However, the problem of equal access to medical care remains. The current continuing outflow of valuable production forces and intellectual resources from Transbaikal leads to the depopulation of small towns, historical settlements and villages. This has a negative impact on the socio-economic development of this border area, which is rich in rare minerals reserves, water resources, forestlands, unique nature reserves, valuable relict plants and rare species of birds and animals. The legacy and the use of valuable historical experience in the fundamental reform of such a strategic sector as health care must be respected, of course, especially at the regional level.

We will endeavour to provide a retrospective analysis of the state health care system's origins in Transbaikal in the 18th century up to the early 1920 s. 
After the Transbaikal region officially became part of the Russian Empire at the beginning of the 18th century, the initial state policy set before the local administration by the central pre-revolutionary government was strictly involved with border and military-fiscal goals and did not envisage the broad development of local health care. But new military, political, economic, trade and socio-cultural conditions led to a change in the social policy vector of the pre-revolutionary government, which in the first half of the 18th century contributed to the foundations of the Transbaikal public health care system.

As part of this process, the main foundation from which the entire public health system of the region developed was mining and metallurgical medicine. It can be said that the emergence of official medicine began in the eastern part of Transbaikal (present-day Zabaikalsky Krai) - an economically important region for the country (Russia's first silver was mined there in 1704 followed by gold in 1722) (Istoriya Buryatii... 2011, p. 76). At the end of the first half of the 18th century (1742), the Nerchinsky Mining Hospital was opened, the goals of which included providing medical support to the silver-smelting and gold mining workforce, as well as the military officials located in the Nerchinsky mining district - an area of 240,000 square kilometers (Malaya entsiklopediya...2011, p. 14). The founders of state medicine in East Transbaikal were physician Zakhar Rik, the doctor's assistants Pyotr Trumler and Yegor Tomilov, and pharmacists Zakhary Tsakhert and Samet (Tsuprik 2014, p. 366). In West Transbaikal (present-day Republic of Buryatia), the formation of a new medical care system began with a military hospital and pharmacy, which opened in 1765 in Selenginsk thanks to the physician Pyotr Lebedev. Medical support for military units was needed due to the uneasy border situation. A battalion infirmary in the city of Verkhneudinsk (Ulan-Ude), headed by the doctor I.F. Resslain became the second inpatient hospital in West Transbaikal at the end of the 1780s (in 1790, the infirmary was reclassified as a military hospital) (Petryaev 1954, p. 45-63).

The civilian system of medical institutions developed much more slowly than those for the military and mining plants. But, as a result of the gradual strengthening of the economic, commercial and legal significance of the region as a whole, the status of Transbaikal's cities also increased. The first of them to receive the right of magistrate administration was Verkhneudinsk (Istoriya Buryatii...2011, p. 84). We have verified the opening date of the Verkhneudinsk civil hospital as $1803 .{ }^{1}$ The physician Klarin Schilling was the organizer of this medical institution. ${ }^{2}$ In 1812 , the civilian hospital was

\footnotetext{
State Archive of the Republic of Buryatia (SARB). F. 11. Op. 1 D. 54. P. 16.

SARB. F. 11. Op. 16. D. 5. P. 1.
}

transferred to a new building that was safe in terms of hygiene. Treatment there was quite expensive and hardly affordable for the poor - locals and "arrivals" alike. In the first quarter of the 19th century, the Verkhneudinsk departmental hospital remained the only urban medical institution on the entire territory of Transbaikal. The second civilian hospital was founded in 1820 in the city of Kyakht (Batoev 1982, p. 10-13), and in 1827 a third city hospital was opened in Nerchinsk (Tsuprik 2014 , p. 366), which became the first on the territory of East Transbaikal. These departmental medical institutions were, in essence, small (20 beds on average), poorly equipped and could not provide qualified medical care to all those in need across such a vast territory.

Due to the constant risk of a fall in the Russian Empire's population, smallpox vaccinations in Transbaikal became an urgent state preventive medicine goal aimed at preserving and increasing the intellectual and productive potential of both the civil and military class in the socio-economic and geopolitically important border area. From 1770, vaccinations began to be carried out in West Transbaikal, and much later, in 1809-1811, in East Transbaikal (beginning in Nerchinsk). According to our data, 1811 should be considered the starting date for government measures for compulsory smallpox vaccination of children and adults, including the military, exiles and convicts, throughout Transbaikal. ${ }^{3}$ The indigenous Buryat population as a whole was willingly vaccinated, while the inhabitants of the Old Believers villages, due to the peculiarities of their way of living, resisted vaccination for a long time (Bolonev 1994). In Transbaikal, it was not possible to organize local production of cowpox matter, therefore, detritus for vaccinations was supplied from St. Petersburg, Orel, Krasnoyarsk and Tomsk. ${ }^{4}$

Due to the gradual expansion of the hospital network in Transbaikal, the personnel shortage became acute. Given this situation, the training of local medical students began. The first medical school was opened in 1762 by doctor's assistant E. Tomilov at the Nerchinsky Zavod Hospital. The school's students were mainly sent out as "travelers to the villages" (Malaya entsiklopediya... 2011, p. 464). The students' medical education was based on knowledge of anatomy, therapy, surgery and Latin. In West Transbaikal, the first teacher of medicine was Pyotr Lebedev, who founded a hospital school in Selenginsk at a military hospital. Later, physician I.F. Resselain also volunteered at the Verkhneudinsk military infirmary to recruit students who "for the people's benefit" helped him to treat patients living far from large settlements, as well as during epidemics (Petryaev 1954, p. 63). This form of training for medical personnel remained in demand in

\footnotetext{
SARB. F. 11. Op. 16. D. 22. P. 1.

4 State Archive of the Transbaikal Territory (SATT). F. 1. Op. 2 (vr). D. 17. P. 18 .
} 
Transbaikal for more than 100 years. At the end of the 19th century, later than in central Russia, systematic training of paramedics and midwives began there. The first obstetrics school to open in Transbaikal, in Chita in 1851, soon closed (Fedotov 1975, p. 190). Only in 1872, at the Chita sub-hospital, was the first military paramedic school founded; it operated until 1905. In 1875, a military obstetrics school was founded in Chita, and it functioned with a short break until 1905. In April 1908, a private obstetrics school with a maternity ward opened in Chita, and it ran until 1911 (Entsiklopediya Zabaykalya... 2000, p. 241-242). The non-systematic work of medical schools in the regional center of Chita did not contribute to solving the personnel problem. Medical specialists worked primarily in urban areas, and the majority of the rural and indigenous population could not yet access affordable medical care.

The specific nature of the foundation and development of the medical sphere in Transbaikal was a result of the pre-revolutionary government's military-political strategy, which initially focused only on providing medical assistance for high priority fields - maintaining a military presence, economic gain and the expediency of its use. In the mid-19th century (1851), as a result of the ongoing administrative and territorial reforms, a special Transbaikal region was created, uniting West and East Tranbaikal. The Transbaikal region's continuing low socio-economic status at the beginning of the second half of the 19th century was a reflection of the general geopolitical situation and political will of the Russian government, where the decisive factor was to ensure the incorporation and development of the Far East (Remnev 2004 , p. 185-186). This was reflected in the regional authorities' structural organization. The simplified form of military-administrative management was aimed at preserving autocracy, including its use in solving medical problems. The management of the local medical and sanitary departments was entrusted to the governors and mayors (Poddubnyy et al. 2014, p. 87). The administration included: the military governor, the regional government, an inspector for the medical unit and the regional prosecutor (Palin 2007, p. 276-288). In 1852, the position of medical unit inspector for the Transbaikal region was introduced, combining the roles of regional and military doctor. The first medical unit inspector was appointed by the Minister of Internal Affairs of Russia by an order of March 13, 1852. The Governor-General of Eastern Siberia by Order No. 64 of March 14, 1852, from the submission of March 3, 1852, of the military governor of the Transbaikal Region, instructing the military doctor of the Transbaikal Cossack Army N.F. Vorozhtsov to hold the post of inspector for the medical department of the Transbaikal Region. ${ }^{5}$ Military officials could also be treated in civilian hospitals, and military doctors provided medical care to the civilian population.

SATT. F. 1. Op. 1 (o) Depository item 35. P. 20-20 both sides.
The number of medical workers and the number of hospitals was planned to be increased in connection with the increase in the number of districts in the region. As a result, in order to increase the effectiveness of health care management, a medical branch of the Transbaikal regional board was founded in 1872, directly subordinated to the military governor and only formally to the Health Department of the Ministry of the Interior. ${ }^{6}$ This centralized the management of medical affairs and provided organizational and methodological control of military and civilian medical institutions.

In 1861, 27 doctors, six medical students and six midwives worked in the Transbaikal region. In 1865, the region was divided into districts. However, the districts' territory remained large, some were densely populated, and medical personnel was insufficient. In 1877, the Verkhneudinsk, Nerchinsk and Troitskosavsk city hospitals and the rural Turkinsky departmental hospital were working in the Transbaikal region. An appraisal of the hospitals was made by the City Government and was approved by the Irkutsk Public Charity Order. ${ }^{7}$ In the regional city of Chita, the first civilian city hospital opened much later - in 1894 - and at first, it only had 10 beds (Tsuprik 2014, p. 228). Verkhneudinsk city hospital was taken as an example for bed capacity and staff. ${ }^{8}$ But, very soon, by 1910 , thanks to the joint efforts of doctors, the city, regional and public administration, the Chita city hospital was transferred to a standardized building and expanded to 110 beds. There was a functioning surgical department with operating, therapeutic, maternity, gynecological and isolated infectious diseases departments. In the same year, for the first time at the Chita City Hospital, 10 free zemstvo district beds were organized (Tsuprik 2014, p. 230). Charity in various forms began to play a significant role in the early 20th century in Transbaikal. Given insufficient state funding, this helped improve the medical situation in the region. A hospital for the poor with 10 beds, opened in 1903 in Sretensk using the charitable funds of the merchant N.S. Pavlov, was of great importance in providing access to medical care, but it was constantly overcrowded (Sretensk. Entsiklopediya Zabaykalya 2014, p. 303). The gradual improvement of the Transbaikal region's socio-economic status contributed to the development of private urban medical care.

Thus, the selection of the city of Chita as a regional center in the mid-19th century had a positive influence on the formation of the public health care system in Transbaikal. Over time, the buildup of qualified and scientific medical personnel and additional sources of funding, both state and public, all made it possible to improve extensive health indicators in Chita over a shorter period of time than in other cities of the region.

\footnotetext{
SATT. F. 1. Op. 1 (o). D. 16514. P. 5

SARB. F. 10. Op. 1. D. 176. P. 20.

SATT. F. Sh. Op. 1. Item 23. P. 2.
} 
Urban sanitary organizations' main focus was the fight against epidemics. In Chita, the Regional Public Health Committee was created. It played a leading role, and all of Transbaikal's district committees in the region were subordinate to it. ${ }^{9}$ The Verkhneudinsk District Public Health Committee functioned from September 1853. It consisted of a chairman and four members: a district doctor, the mayor, a dean archpriest of one of the churches of Verkhneudinsk and a military doctor of the 1st cavalry army of the Transbaikal Cossack army. ${ }^{10}$ The duties of the Verkhneudinsk District Public Health Committee included: 1) monitoring the emergence and spread of infectious epidemic diseases among the population and domestic livestock in the Verkhneudinsk district of the Transbaikal region; 2) eliminating outbreaks of epidemic diseases in a timely manner. At the beginning of the second half of the 19th century, the foundations of sanitary measures began to be developed in Transbaikal in urban medical conditions, although all the responsibilities for this were assigned to the city doctors and police officers. There was a designated plan for medical and sanitary measures taken in the event of an epidemic situation among the population and animals. ${ }^{11}$ The formation of urban sanitary organizations in the vast territory of Russia proceeded extremely unevenly, both in terms of timeframes and in terms of implementation (Egorysheva et al. 2017, p. 87). District committees in Transbaikal were concentrated in cities and carried out necessary tasks throughout large districts. Positive results (a reduction in mortality and disability levels) with timely responses for medical assistance requests contributed to the fact that residents of Transbaikal began to acknowledge the benefits of official medicine. As a result, during this period, forms of preventive medical and sanitary measures appeared in the Transbaikal region that were later recognized and successfully implemented in the health care model for Soviet Russia.

In the wake of the public movements of the 18601870 s, medical societies were created on a massive scale, including in this Russian province (Poddubnyy et al. 2014, p. 88). At the end of the 19th century, thanks to improvements in socio-economic conditions in the region, the creation of the Transbaikal Medical Society became possible, which demonstrated the demand for professional medicine. The Transbaikal Medical Society was the second after one in Irkutsk (1858) to be created in East Siberia. Its charter was approved on October 16, 1892, and on January 14, 1893, members of the society gathered for their first meeting. ${ }^{12}$ The founders of the Transbaikal Medical Association were V.Ya. Kokosov, N.V. Kirilov, and P.S. Alekseev. The organizational, methodical, treatment, prophy-

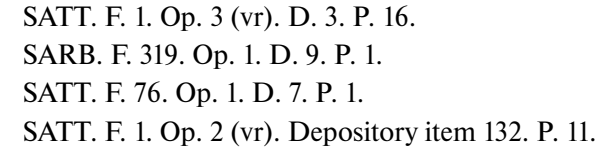

lactic, educational and charitable activities of the society were combined on a scientific basis providing for an improvement in the quality of public health care measures in Transbaikal. At regular meetings, doctors had the opportunity to discuss medical successes and existing problems. The attendance of physicians' assistants at these meetings greatly enriched their knowledge and experience. The publication of a medical journal in November 1922, shortly before the end of the Transbaikal Medical Society's activities, contributed to the expansion of the scientific and methodological field. This, in turn, meant that in the Russian province, the latest achievements of world and domestic medicine were already being successfully applied in order to improve medical diagnostic and preventive work. At the end of the 19th to the beginning of the 20th century, there was an improvement in the medical field in Transbaikal, expressed in the emergence of specialized urban medical care. Medical diagnostic and personnel levels in the regional center (Chita) were already comparable with levels in the major cities of the Russian Empire.

One of the peculiar features of health care in Siberia was the emergence of mining medicine, due to the development of the gold mining industry. ${ }^{13}$ E.V. Bek became the Nerchinsky Mining District's medical inspector on June 25, 1912, replacing Dr. N.V. Berlinsky, who had held the post for six years and retired. It turned out that for more than 10 years the level of medical care at the mines had not only failed to improve, but significantly deteriorated. As a result of inspections, a number of shortcomings were identified, both in terms of the organization of treatment processes and the sanitary and hygienic conditions of hospital stays. The lack of trained medical personnel was also noted. At a meeting of the Mining Council, held on December 3, 1912, doctor E.V. Bek's critical remarks and suggestions for the improvement in the quality of medical care provision for mining workers and their families were considered, many of which were accepted for implementation. The implementation of the plan was prevented by the outbreak of World War I and the death of the doctor himself (Tsuprik 2010, p. 140).

From the mid-1880s, the question of constructing a railway line, which was supposed to stretch from east to west across the entire country, was actively discussed in Russia. On July 1, 1900, the official commencement of daily rail traffic along the Irkutsk-Sretensk section took place. As a result, the cities of Transbaikal were connected by the Trans-Siberian Railway, which was of great cultural, political and socio-economic importance for the development of this region in the pre-revolutionary period. On August 15, 1899, the first train arrived in Verkhneudinsk. In May 1900, a railway hospital with 25 beds was opened at the station. The first doctor to provide medical care to the workers, railway builders

SATT. F. 1. Op. 2 (vr). Depository item 241. P. 22-25. 
and their families was V.V. Natanson, who worked as a general practitioner and pediatrician. ${ }^{14} \mathrm{He}$ was the head of the Verkhneudinsk railway hospital until 1917. Honorable doctor and the first surgeon of the railway hospital of Verkhneudinsk station was I.I. Alekseev. ${ }^{15}$ On March 25, 1918, he was appointed senior physician of the Verkhneudinsk railway hospital. From this point, the inpatient surgical department was created and outpatient treatment for surgical patients was conducted. A little later, in July 1900, a railway hospital opened in Chita with 35 beds, of which 10 were for infectious diseases patients, having a staff of 17 to provide medical support for passengers, railway workers and their families. By 1917, the hospital already had 80 beds.

The Chita transit prison opened in 1861, replacing the former stockades and semi-stockades. Local doctors were advised to provide medical assistance to prevent various complications and deaths among prisoners and exiles. For medical and prophylactic purposes, vaccinations were provided, including for children. Additional funds and medicines were allocated for this (Mannov 2002, p. 92). On March 16, 1872, a prison hospital with 20 beds was opened in one of the free cells of the Chita prison. In 1875, a contract was signed for the construction of a hospital building on the prison territory. It was completed only in 1884 . If $\mathrm{X}$-rays were necessary, patients went to the $\mathrm{x}$-ray facility of the Transbaikal Sisters of Mercy community, with a cash settlement from the prison administration. A surgical department in the prison hospital was created on November 2, 1912, in the women's department. It consisted of three wards - operating, surgical and dressing. As there was no surgeon on staff at the prison hospital, the General Prison Administration allowed a surgeon to be invited from outside and paid him 10 rubles for each operation, but at the same time he was obliged to also treat patients from Nerchinsk labor camp (Pogodaeva 2017, p. 52-61). Medical institutions that worked in the Transbaikal region were thus subordinated to different governmental agencies. At the same time, various specialists could provide medical care in any hospital on the basis mutual settlements.

Departmental differences forced a military medical service to be developed from the second half of the 18th century. In 1851, in Chita in East Transbaikal, in connection with the formation of the Transbaikal Cossack Army, a military infirmary was established, which after six years was reorganized and equipped as a military semi-hospital with 75 beds. ${ }^{16}$ This was a significant step aimed at improving health care in the area. During the Russo-Japanese War of 1904-1905, the Chita military semi-hospital was expanded to 400 beds and supervised the medical activities of all reserve and mobile field hos-

14 SATT. F.R. 1114. Op. 2. Depository item 37. P. 1.

15 State Archive of Tomsk Region (SATR). F. 102. Op. 2. D. 88. P. 16.

16 Russian State Military Historical Archive (RSMHA). F. 879. Op. 2. Depository item 1489 P. 1. pitals in the region. Given that the territory of Transbaikal is bordered by Mongolia and China, in 1853 at the government level a regulation on obligatory vaccination was adopted specially for the Transbaikal Cossack troops, clearly regulating the legal, medical and organizational activities in this field. ${ }^{17}$ Thus, a procedure was developed for carrying out vaccinations in the Transbaikal Cossack Army. The timeframes for vaccinations and the conditions for revaccination were set. Procedures for issuing and submitting reporting documentation were specified. Measures for dealing with culpability, vaccination evaders and methods of exertion on them were specified. Conditions for pox material's storage and maintenance of stocks were specified. All these measures were aimed at improving the demographic situation, maintaining a favorable epidemiological and sanitary regime in a strategically important border area.

By the end of the 19th century, there were a number of military medical institutions in the Transbaikal Cossack Army: four military hospitals (with 190 beds), one hospital unit (with six beds), eight emergency wards (with 39 beds) and 12 medical points (without beds). By the end of the 19th century, four military departments with medical personnel and medical institutions with beds were formed for the effective management of the existing three military departments, covering the entire territory of the Transbaikal region. Troitskosavsk, Selenginsk, Verkhneudinsk districts (West Transbaikal) belonged to the 1st military department, Akshinsk district belonged to the 2nd military department, Chita and Nerchinsk districts belonged to the 3rd, and Nerchinsky Zavod district (East Transbaikal) belonged to the 4th (Epov 1889, p. 20). Over 32 years (1887-1919), the number of army hospitals did not increase, and bed capacity only increased by 10 beds, however, the number of reception rooms increased by 13 and the bed capacity in them rose from 39 to 186 places, and medical attendants appeared. The structural organization for providing medical assistance to the Cossack troops was only fully formed on the eve of World War I. In general, the progressive extensive development of the military medical industry, the introduction of the district principle for medical care of the Cossack population and improvement in the quality of obstetric care can be noted. In July 1914, the Chita hospital was assigned the status of a large center of military medical importance (1,000 beds) (Lim et al. 2016, p. 56-62).

The formation of local branches of the Russian Red Cross Society (RRCS) in the Transbaikal region began at the end of the 19th century. The main goal of these medical and social structures was to train local sisters of mercy, provide direct medical assistance and care for the wounded and sick soldiers, not excluding the local population, and organize anti-epidemic efforts. On May 8, 1894, in the Transbaikal region, the Transbaikal (Chita)

\footnotetext{
17 RSMHA. F. 879. Op. 2. Depository item 931. P. 7.
} 
RRCS local administration was founded with its center in Chita, headed by the military governor (Skazhutin 2016, p. 88). Nine local committees were also created, the largest of which was located in Verkhneudinsk. Only four of the committees functioned most actively - Verkhneudinsk, Sretensk, Akshinsk and Khiloksk. On February 27, 1908, the Verkhneudinsk local committee was transformed into the Verkhneudinsk local government of the RRCS, which significantly expanded its powers. ${ }^{18}$ With the continuing shortage of medical institutions and qualified medical personnel in the Transbaikal region, the activities of local departments and local committees of the RRCS, with its organizational, technical and personnel base, gained significant importance for the entire population (Fadeeva 1992, p. 68-69). Employees of the RRCS provided qualified medical assistance in hospitals and medical receptions in outpatient medical points, and also took measures to prevent epidemics of various infectious diseases in the border area of the Russian Empire (Oksenyuk 2015, p. 36).

To create the basis of health care for rural areas, qualified personnel and a network of hospitals were needed first of all. The rural and indigenous population was provided with service only when staff undertook rural field rounds and in acute epidemic situations. The introduced traveling field system of serving the rural population did not justify itself and was of a formal nature due to long distances, low population density and poor roads. In the second half of the 19th century, the government of the Russian Empire and the medical community were aware of the difficulty of implementing measures aimed at resolving accute issues. The need for qualified medical personnel to provide quality medical care to the rural population led to the the first medical faculty opening at the end of the 19th century (1888) beyond the Urals, as part of Imperial Tomsk University. Financial and material support measures taken by the pre-revolutionary government were aimed at attracting doctors, paramedics and midwives to Transbaikal. However, despite this, there were few specialists willing to stay. The shortage of medical personnel was not eliminated until the early 1920s. The organization of state medical care for the rural population of the Transbaikal region took longer and more effort than in the European part of the country. But, work in this field did not stop in pre-revolutionary Transbaikal. In the Transbaikal region, a county administrative-territorial division was created and the settlements of each county were divided into medical districts. Despite financial, economic and personnel problems, in 1901-1903, the transition to a divisional principle for providing medical services to the population was implemented in Transbaikal. ${ }^{19}$ Eighteen district doctor and 36 medical assistant positions were added to the new staff. According to the project outline, distribution

\footnotetext{
18 SARB. F. 10. Op. 1. D. 1019. P. 6.

19 SATT. F. 1. Op. 2 (vr). Depository item 189. P. 6306.
}

of the medical precincts among the new rural medical staff in the districts of the Transbaikal region in 1901 was to consist of 15 medical precincts in five districts: in the Chita district there was to be three, in Verkhneudinsk four, in Selenginsk - four, in Nerchinsky Zavod - two and in Barguzinsk - two. ${ }^{20}$ In Nerchinsk, Akshinsk and Troitskosavsk precincts with their exclusively Cossack population, local doctors were located in precinct cities. The district doctors of these counties were also entrusted with carrying out forensic and medical law enforcement duties as well as medical support for the indigenous people. The indigenous people of Transbaikal, with their nomadic and semi-nomadic lifestyles, like the Old Believers did not fully trust official medicine, which created additional difficulties in implementing plans to restructure the available system of medical care. Densely populated districts required more medical staff.

In general, there were positive changes in health care provision in Transbaikal at the beginning of the 20th century. This was reflected in the increase in the number of doctors: there were already 110 doctors in the region (in Chita - 31, Verkhneudinsk - eight, Nerchinsk - four, Troitskosavsk - six, Aksha - five, Selenginsk two, Nerchinsky Zavod - three, Barguzin - two; in the precincts: Chitinsk precinct - seven, Verkhneudinsk precinct - eight, Akshinsk precinct - three, Nerchinsk precinct -16 , Troitskosavsk precinct - three, Nerchinsky Zavod precinct - seven, Selenginsk precinct three, Barguzinsk precinct - two). Midwife-paramedics and midwives numbered 82 people (Lazareva and Sergeev 2006, p. 42). In 1908, the Chita city council issued a request that zemstvo district funds that were collected by public charities and sent to Irkutsk be used to build a zemstvo district hospital for the rural population of Chita county in Chita. The expediency of building a hospital in Chita was due to the majority of qualified medical personnel being located in the city. At the 1st congress of doctors in the Transbaikal region in 1912, the issue of building a regional district hospital for Chita's rural population was actively discussed: "Chita is almost the only provincial city in Russia that does not have a provincial hospital" (Trudy syezda... 1918, p. 6). Only on July 7, 1913, was a provision on district doctors and paramedics enacted, which provided for an increase in staff and a raise in the salaries of precinct doctors. There were already 27 precinct doctor positons, one doctor per precinct. Accordingly, it was planned to divide the Transbaikal territory into smaller precincts in order to increase the ramified structuring of the medical network. Doctors' salaries increased from 1,700 rubles to 2,000. The first zemstvo district hospital (with 20 beds) opened in Chita in 1916 and was constantly overcrowded. In mid-1920, for a brief period, the zemstvo district hospital in Verkhneudinsk had 115 beds; surgical, dermatovenerologic, internal and fe-

20 SATT. F. 1. Op. 2 (vr). Depository item 189. P. 31. 
male diseases departments were created. Separately, 10 beds were allocated for the treatment of the indigenous population. The number of rural physicians and private practitioners increased. The medical community in Transbaikal understood that fundamental changes were needed in health care management.

At the end of 1917 in the Transbaikal region, a draft of measures was being prepared for the creation of a comprehensive rural medical system. At that time, an extensive method for managing medicine on the fringes of the Russian Empire was a decisive factor in ensuring access to medical care in Transbaikal. But the implementation of these plans was prevented by the revolution in Russia and its consequences.

For the first time, a Ministry of Health was created within the framework of the Far Eastern Republic (FER). This solved urgent problems and tasks using centralized management in a unified manner, which was very important during a period of the continuing shortages of qualified medical personnel and medical institutions. During this period, the Ministry of Health primarily had to fight epidemics, organize medical and preventive care for the general population, and provide medical support to the people's revolutionary army. Throughout the entire territory of the FER, publicly available and free medical care was introduced for all types of workers. In 1921, 13 years after the decision to create it was taken, the first rural hospital for indigenous people was built and began to function in Aginsk Steppe. Three years later, there was an urgent need to expand it: the hospital was housed in a new building and received additional logistical and medical diagnostic equipment. The introduction of the Soviet system of public health care principles in Transbaikal was only possible after its territory was included in RSFSR. On November 10, 1922, the Transbaikal region was renamed Transbaikal governorate, which included Akshinsk, Aleksandrov Zavod, Nerchinsky Zavod, Sretensk, Chita and Petrov districts, and was liquidated on January 4, 1926, during the rezoning of the Far East (Ocherki istorii... 2009, p. 200-201). By 1926, Transbaikal was divided administratively and geographically into Siberian (Buryat-Mongolian Autonomous Soviet Socialist Republic) and the Far Eastern sections (Sretensk and Chita districts).

A retrospective analysis suggests that the health care system of Transbaikal (present-day Republic of Buryatia and Zabaikalsky Krai) followed a difficult path. The pre-revolutionary Russian government's state policy for the provision of medical care in the region evolved in accordance with changing priorities for the development of Transbaikal's territory as a single political, economic and socio-cultural space within the country. This provides us with a more complete picture of the peculiar features found during the birth of the professional medical system in Transbaikal. The formation of medical care in Transbaikal can be divided into three stages. From the end of the first half of the 18th century to the beginning of the 19th century, two stages emerged and took form: mining and military medicine (the first stage), and urban medicine (the second stage). The third stage is characterized by the formation of rural health care, which received priority at the end of the 19th century, but could not solve the personnel problems through investments and benefits alone. In general, for the development of effective health care in the region, the creation of favorable socio-economic and socio-cultural conditions were needed as well as the introduction of principles of sanitary hygiene into everyday practice. At the beginning of the 1920s, the institution of zemstvo medicine began to be founded in Transbaikal. An extensive method for organizing medical care was becoming a decisive factor for ensuring accessibility to treatment and preventive care in Transbaikal. When the socio-economic structure changed, the traditions of pre-revolutionary medicine (as it was in 1917) and medicine that met the requirements of the new state remained. The basic requirements were kept - medical care in Transbaikal needed to be affordable and of high quality. The country's leadership understood it was impossible to effectively meet the goals of constructing socialism without health care for the adult population and protecting the life and health of children throughout the territory of the former Russian Empire. Medical management was centralized, all activities were carried out in a coordinated and systematic manner. The priority task was to ensure equal access to qualified medical care wherever people resided. The personnel issue began to be resolved, and national medical staff, both high- and mid-level, began to be systematically trained. By the end of the first quarter of the 20th century, across the territory of Transbaikal, maternal and infant mortality gradually decreased, epidemic outbreaks of various infectious diseases decreased, an increase in the life expectancy and a natural increase in the population were registered. The foundation of public health care created in pre-revolutionary Transbaikal was successfully used and transformed into an effective Soviet model of public health. The relevance of the preservation and reasonable reforms of Transbaikal's regional health care system, i.e. well-tested and adapted to the complex socio-economic, geographical and climatic conditions, can be noted.

\section{References}

Batoev DB (1982) Spodvizhniki zdravookhraneniya [Health care associates]. Ulan-Ude: Buryatskoe knizhnoe izdatelstvo. 128 p. (In Russ.)
Bolonev FF (1994) Staroobryadtsy Zabaykalya v XVIII - XX vv. [Old Believers of Transbaikalia in the 18th - 20th centuries]. Novosibirsk: AOZT. Izd-vo "Fevral”. 148 p. (In Russ.) 
Egorysheva IV, Sherstneva EV, Goncharova SG (2017) Meditsina gorodskikh obshchestvennykh samoupravleniy v Rossii [Medicine of urban public governments in Russia]. Moscow: Shiko. 176 p. (In Russ.)

Entsiklopediya Zabaykalya. Chitinskaya oblast [Encyclopedia of Transbaikalia. Chita region] (2000) SO RAN Chit. in-t prirodnykh resursov [Siberian Branch of the RAS Chita Institute of Natural Resources].Vol. 1. Novosibirsk: Nauka. 301 p. (In Russ.)

Epov NI (1889) Zabaykalskoe kazachie voysko [Transbaikalian Cossack army]. Nerchinsk: Tipografiya M.D. Butina. 76 p. (In Russ.)

Fadeeva AP (1992) 125 let so dnya rozhdeniya ROKK [25th anniversary of the birth of the Russian Red Cross Society]. Kalendar znamenatelnykh i pamyatnykh dat istorii zdravookhraneniya Chitinskoy oblasti na 1992 g. [Calendar of significant and memorable dates in the history of health care in the Chita region in 1992]. Chita. P. 27-31. (In Russ.)

Fedotov NP, Mendrina GI (1975) Ocherki po istorii meditsiny i zdravookhraneniya Sibiri [Essays on the history of medicine and health in Siberia]. Tomsk: izd. Tom. un-ta. 280 p. (In Russ.)

Istoriya Buryatii. T.II. XVII - nachalo XX v. [History of Buryatia. Vol. 2. 17 th - the beginning of the 20th century] (2011) Ed. by B.V. Bazarov. Ulan-Ude: Izdatelstvo BNTs SO RAN. 621 p. (In Russ.)

Lazareva SI, Sergeev OI (2006) Rol gorodskikh dum Dalnego Vostoka $\mathrm{v}$ aktivizatsii sotsialnoy raboty (90-e gg. XIX v - 1917 g.) [The role of the city duma of the Far East in the revitalization of social work (90s of the 19th century - 1917)]. OYKUMENA. Regionovedcheskie issledovaniya. Nauchno-teoreticheskiy almanakh [Ecumene. Regional studies. Theoretical Almanac]. Issue 1. Dalnauka. Vladivostok. P. 33-43. (In Russ.)

Lim V, Zagalaev B, Kunitskiy N, Khazhikhanova E (2016) 17 marta 165 let so dnya osnovaniya 321 voennogo klinicheskogo gospitalya [March 17, 165 years since the founding of 321 military clinical hospital]. Kalendar znamenatelnykh i pamyatnykh dat istorii zdravookhraneniya Zabaykalskogo kraya [Calendar of significant and memorable dates in the history of public health in the Trans-Baikal Territory]. Chita. P. 56-62. (In Russ.)

Malaya entsiklopediya Zabaykalya (zdravookhranenie i meditsina) [Small Encyclopedia of Transbaikalia (health care and medicine)] (2011) Ed. by R.F. Geniatulin. Novosibirsk: Nauka. 628 p. (In Russ.)

Mannov AA (2002) 130 let Chitinskoy tyuremnoy bolnitse (1872 g.) [130 years of the Chita prison hospital (1872)]. Kalendar znamenatelnykh i pamyatnykh dat istorii zdravookhraneniya Chitinskoy oblasti [Calendar of significant and memorable dates in the history of health care in the Chita region]. Chita. P. 29-36. (In Russ.)

Ocherki istorii Zabaykalskogo kraya. T. 1-2 [Essays on the history of the Trans-Baikal Territory. Vol. 1-2] (2009) Ed. by I.I. Kirillov, N.V. Gordeev. Chita: Ekspress-izdatelstvo. 440 p. (In Russ.)

Oksenyuk EV (2015) Deyatelnost Rossiyskogo Obshchestva Krasnogo Kresta v nachale XX veka (1903-1914) [The activities of the Russian
Red Cross Society in the early 20th century (1903-1914)]. Moscow: Izd-vo PSTGU. 136 p. (In Russ.)

Palin AV (2007) Rol gosudarstva v khozyaystvennom i sotsiokulturnom osvoenii Aziatskoy Rossii XVII - nachala XX veka [The role of the state in the economic and socio-cultural development of Asian Russia in the 17 th - early 20 th century]. Sbornik materialov regionalnoy nauchnoy konferentsii [Collection of materials of the regional scientific conference]. Novosibirsk. P. 27-288. (In Russ.)

Petryaev ED (1954) Issledovateli i literatory starogo Zabaykalya: Ocherki iz istorii kultury kraya [Researchers and writers of the old Transbaikalia: Essays from the history of culture of the region]. Chita. 260 p. (In Russ.)

Poddubnyy MV, Egorysheva IV, Sherstneva EV et al. (2014) Istoriya zdravookhraneniya dorevolyutsionnoy Rossii (konets XVI - nachalo XX v.) [The history of health care in pre-revolutionary Russia (end of the 16th - early 20th centuries)]. Ed. by the Academician of RAMS R.U. Khabriev. Moscow: GEOTAR-Media. 244 p. (In Russ.)

Pogodaeva GI (2017) Mart k 100-letiyu zakrytiya Nerchinskoy katorgi (1917g.) [March to the 100th anniversary of the closure of Nerchinsk penal servitude (1917)]. Kalendar znamenatelnykh i pamyatnykh dat istorii zdravookhraneniya Zabaykalskogo kraya na 2017 g [Calendar of significant and memorable dates in the history of public health in the Trans-Baikal Territory in 2017]. Chita. P. 52-61. (In Russ.)

Remnev AV (2004) Rossiya Dalnego Vostoka. Imperskaya geografiya vlasti XIX - nachala XX vekov [Russian Far East. Imperial geography of power 19th - early 20th centuries]. Omsk. 552 p. (In Russ.)

Skazhutin DV (2016) 115 let so dnya otkrytiya Zabaykalskoy obshchiny sester miloserdiya Krasnogo Kresta (1901 g.) [115 years since the opening of the Trans-Baikal Community of the Red Cross Sisters of Mercy (1901)]. Kalendar znamenatelnykh i pamyatnykh dat istorii zdravookhraneniya Zabaykalskogo kraya [Calendar of significant and memorable dates in the history of public health in the Trans-Baikal Territory]. Chita. P. 88-100. (In Russ.)

Sretensk. Entsiklopediya Zabaykalya [Encyclopedia of Transbaikalia] ( 2014) Ed. by K.K. Ilkovskiy. Chita. 444 p. (In Russ.)Trudy syezda meditsinskih rabotnikov Zabaykalskoy oblasti 1-5 noyabrya $1917 \mathrm{~g}$ [Proceedings of the Congress of Medical Workers of the Transbaikal Region, November 1-5, 1917] (1918) Chita: Elektro-Tipografiya Pervunitskogo. 134 p. (In Russ.)

Tsuprik RI (2010) 145 let so dnya rozhdeniya doktora meditsiny E.V. Beka (1865-1915 gg.) [145 years since the birth of doctor of medicine E.V. Bek (1865-1915)]. Kalendar znamenatelnykh i pamyatnykh dat Zabaykalskogo kraya 2010 [Calendar of significant and memorable dates of the Trans-Baikal Territory 2010]. Chita. P. 138-147. (In Russ.)

Tsuprik RI (2014) Literaturnoe, istoricheskoe i meditsinskoe kraevedenie [Literary, historical and medical study of local lore]. Izbrannye trudy issledovateley Zabaykalya [Selected Works of Transbaikalia Researchers]. Compl. by N.A. Burdiyan, G.I. Pogodaeva; Ed. by M.V. Konstantinov. Chita: ZabGU. 456 p. (In Russ.)

\section{About the author}

Sergey Dashidondokovich Batoev - Candidate of Medical Sciences, Assistant Professor at the Department of Human Studies, Institute of Social Science, FSAEI HE I.M. Sechenov First MSMU MOH Russia (Sechenov University), Moscow. Email: sbatoev@list.ru 